\title{
EXAMINE THE EFFECT OF PARENT'S SUPPORTS TOWARD THE CHAMPION MOTIVATION POSSESSED BY ATHLETES SAMARINDA IN 2018
}

\section{Nanda Alfian Mahardhika, Yulia Tri Kusumawati, Jeane Betty Kurnia Jusuf, Januar Abdilah Santoso, Andri Tria Raharja, Julianur}

Faculty of Teacher Training and Education, Universitas Muhammadiyah Kalimantan Timur. Jl. Ir. H. Juanda No. 15, Samarinda, East Kalimantan 75124, Indonesia. E-mail:

\begin{abstract}
The aim of this research is to examine the effect of parent's supports toward the champion motivation possessed by athletes in Samarinda city. This research method used in this research is descriptive qualitative method. The instrument of research is the questionnaires shared to 50 parent's Silat athletes in Samarinda. The population of this research is all parent's athletes and Silat athletes in Samarinda. The saturated sample research technique is used to the all over population as the sample and it presented in the percentage term. This research is expected to be done in 6-month periods. The result of this research is that the support parent's athletes gained a positive trend with $93.4 \%$ and the champion motivation of athlete also had the same pattern with $97.2 \%$.
\end{abstract}

Keywords: parent's, the champion motivation, athlete,pencak silat, samarinda

\section{INTRODUCTION}

Pencak Silat as a heritage of the Indonesian people is a senior martial art that is in accordance with the personality of the Indonesian nation. Unrelated martial arts, art and spiritual sports are incorporated into a unit that is united and cannot be approved. The training is athletic, as it is in sport and professional dance, yet the competence that the martial arts teach stands apart from those of sport or dance by means of its external, instrumental value as a weapon. It is precisely this external, instrumental effectiveness, the weapons potential of martial arts, that accounts for the striking beauty of its movements. (Bowman, P \& Judkins, B.N., 2016).

At the moment Pencak Silat is very popular with the wider community and also the Pencak Silat sports for the first time entering the sports contested at the 2018 Asian Games in Jakarta and Palembang. According to Nugroho (2007) said that on September 22-23 1979 a conference was held at the International Pencak Silat Federation which was attended by several neighboring countries, including: Singapore, Malaysia, Brunei Darussalam, and 
Indonesia as the host. On the level technique, competitions prompted a radical alteration of traditional styles and training styles and training practices. The point system used in competitions gives scores of one point for a clean punch, two for a kick, and three for a 'drop'. (Wilson, A.D, 2002).

The main factor that can spur the development and achievement of martial arts athletes is the increase in quality in coaching, training and improvement of facilities and infrastructure. There is a lot of knowledge that is closely related to pencak silat, among others: anthropometry, sports psychology, anatomy, biomechanics, sports physiology and training programs provided by the trainer. In order to be able to do the technique properly and properly, good biomotor capabilities are needed. The biomotor ability needed in pencak silat is power, coordination, and accuracy in the target field. (Nugroho, 2005).

In 2018, the Province of East Kalimantan held a Provincial VI Sports Week in East Kutai. There are many sports that are competed in East Kutai Provincial Sports Week, one of which is the martial arts. At present pencak silat in East Kalimantan Province can be said to have developed, because there are several athletes from the Province of East Kalimantan who have penetrated the National and even International champions.

Pencak silat in Samarinda City is currently conducting training camps at the Martial Arts Hall in Air Hitam Polder. The contingent of Pencak Silat Kota Samarinda targeted by KONI Samarinda could retain the title of General Champion I, the same as the results of the previous 2013 Provincial Sports Week V. Therefore the support of the athlete's parents is very important to increase the achievement motivation of Pencak Silat athletes in Samarinda City. Such support can be in the form of encouragement to always be passionate about training, support during training and during competition and also the prayers of both athletes' parent's.

This General Champion Target I is what increases the motivation of pencak silat athletes in Samarinda City during training. In the end the Samarinda City contingent VI, the Pencak Silat sporting event, managed to become the first winner with 11 gold medals.

\section{METHOD}

This research is a quantitative descriptive study that aims to determine parental support for the achievement motivation of Samarinda City martial arts athletes in the Sports Week of East Kalimantan Province. According to Arikunto, S (2010) that descriptive research is research that intends to describe or describe something, such as circumstances, conditions, situations, events, activities, and others. The method used is a survey, the data collection 
technique uses a questionnaire, the scores obtained are analyzed using quantitative descriptive analysis as outlined in the form of a percentage.

This research was conducted in the Pencak Silat Hall in Samarinda's Black Water Polder. Data collection was carried out on November 2, 2018 - November 18 2018. The subjects of this study were parents of athletes and martial arts athletes in Kota Samarinda with a total of 50 respondents.

Population is a generalization area consisting of: objects / subjects that have certain qualities and characteristics set by the researcher to be studied and then conclusions drawn, (Sugiyono, 2013). The population in this study were all parents of athletes and athletes in Samarinda martial arts in the Sports Week of East Kalimantan Province in 2018. In this study using a saturated sampling technique that is sampling technique if all members of the population are used as a sample (Sugiyono, 2013), or in other words this study is a population research with samples of all parents of athletes and athletes from Samarinda in the East Kalimantan Sports Week Year 2018 with 25 people.

This research was conducted to collect data used as a basis for determining the feasibility of research. Techniques and instruments for data collection must be determined precisely so that accurate data is obtained in accordance with the problems and objectives of the study.

The instrument used to collect data in this study is a questionnaire. The instrument is used as a data collection tool from experts, trainers and athletes in connection with criticism, suggestions and improvements that are useful for the research. Before the experts and subjects filled out the questionnaire for data collection, it was explained in advance some ways to fill out the questionnaire. To give a score of each statement answered by the respondent by checking yes or no. In the process of parental support for the achievement motivation of pencak silat athletes in Samarinda City.

\section{FINDINGS AND DISCUSSION}

\subsection{Data analysis}

The data analysis technique in this study used descriptive statistical techniques as outlined in the form of percentages:

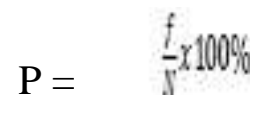

\section{Information:}

$\mathrm{P}=$ percentage of yield

$\mathrm{f}=$ frequency of subjects

$\mathrm{n}=$ total number 
Table 1. Norms for Assessment Criteria

\begin{tabular}{cc}
\hline Value & Category \\
\hline $81-100 \%$ & Very Good \\
$61-80 \%$ & Well \\
$41-60 \%$ & Pretty Good \\
$21-40 \%$ & Less \\
\hline $0-20 \%$ & Very Less \\
\hline
\end{tabular}

(Akbar, 2013)

Data from research on parental support for achievement motivation Samarinda City Pencak Silat athletes in the Provincial VI Sports Week of East Kalimantan are presented in the form of a parent support questionnaire, for more details can be seen in the following table:

Table 2. Parental support

\begin{tabular}{clcc}
\hline \multirow{2}{*}{ No } & \multicolumn{1}{c}{ Aspects Assessed } & \multicolumn{2}{c}{ Choice of Answers } \\
Yes & No \\
\hline 1 & Do parents support your profession as a martial arts athlete? & 50 & 0 \\
\hline 2 & Do parents accompany you when you compete? & 45 & 5 \\
\hline 3 & Do parents ask about the progress of your training? & 46 & 4 \\
\hline $\begin{array}{l}\text { Are parents concerned with the development of your } \\
\text { achievements? }\end{array}$ & 44 & 6 \\
\hline 5 & Do parents pay special attention when you compete & 44 & 6 \\
\hline 6 & During training / competition, do parents pray for you? & 47 & 3 \\
\hline 7 & $\begin{array}{l}\text { Do your parents always encourage you to continue to } \\
\text { practice? }\end{array}$ & 49 & 1 \\
\hline 8 & Do your parents provide your support when at home? & 47 & 3 \\
\hline 9 & Do your parents provide free time to practice? & 46 & 4 \\
\hline 10 & $\begin{array}{l}\text { Do parents prepare additional equipment and purchase } \\
\text { vitamin supplements for you? }\end{array}$ & 50 & 0 \\
\hline Total score & 468 & 32 \\
\hline $\begin{array}{l}\text { Maximum Number of Scores } \\
\text { Percentage of Assessment }\end{array}$ & $\begin{array}{c}500 \\
\mathbf{9 3 , 4 \%}\end{array}$ & $\begin{array}{c}500 \\
\mathbf{6 , 6 \%}\end{array}$ \\
\hline Category & $\begin{array}{c}\text { Very } \\
\text { Good }\end{array}$ & $\begin{array}{c}\text { Very } \\
\text { Less }\end{array}$ \\
\hline
\end{tabular}

Figure 1. Support of Athletes' Parents

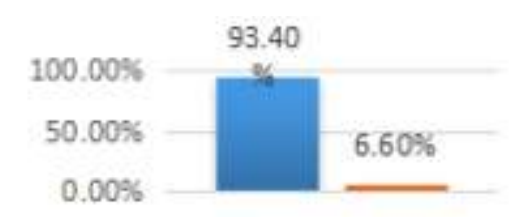


Based on the table and diagram above, it can be explained as follows:

1. Assessment of parental support for achievement motivation of Pencak Silat athletes in Kota Samarinda which answers yes to the display aspect shows that in the category it is very good, with a percentage of $93.40 \%$.

2. An assessment of parents' support for achievement motivation in Pencak Silat athletes in Kota Samarinda, which answered no aspirations, showed that it was in a very good category, with a percentage of $6.60 \%$.

Based on the results of filling in the questionnaire, the relationship between parents' support for achievement motivation in Samarinda City pencak silat athletes was very good with a category of $93.40 \%$.

Table 3. Achievement Motivation

\begin{tabular}{|c|c|c|c|}
\hline \multirow{2}{*}{ No } & \multirow{2}{*}{ Aspects Assessed } & \multicolumn{2}{|c|}{ Choice of Answers } \\
\hline & & Yes & No \\
\hline 1 & Do you always pray before practice and compete? & 49 & 1 \\
\hline 2 & $\begin{array}{l}\text { Do you learn the techniques and tactics given by the } \\
\text { trainer? }\end{array}$ & 50 & 0 \\
\hline 3 & Do you pay attention to the coach in giving direction? & 50 & 0 \\
\hline 4 & Do you prepare personal needs when going to practice? & 46 & 4 \\
\hline 5 & $\begin{array}{l}\text { Do you practice independently when you practice with } \\
\text { the holiday team? }\end{array}$ & 44 & 6 \\
\hline 6 & $\begin{array}{l}\text { Have you studied the lack of techniques and tactics by } \\
\text { watching video recordings? }\end{array}$ & 47 & 3 \\
\hline 7 & Are you happy and comfortable when practicing? & 50 & 0 \\
\hline 8 & $\begin{array}{l}\text { Are you discussing with coaches or athletes friends to } \\
\text { improve techniques? }\end{array}$ & 50 & 0 \\
\hline 9 & Are you diligent in practicing? & 50 & 0 \\
\hline 10 & $\begin{array}{l}\text { Do you want to get the best results in East Kalimantan } \\
\text { Provincial Sports Week 2018? }\end{array}$ & 50 & 0 \\
\hline \multicolumn{2}{|r|}{ Total score } & 486 & 14 \\
\hline \multicolumn{2}{|c|}{ Maximum Number of Scores } & 500 & 500 \\
\hline \multicolumn{2}{|c|}{ Percentage of Assessment } & $97,2 \%$ & $2,8 \%$ \\
\hline \multicolumn{2}{|c|}{ Category } & $\begin{array}{l}\text { Very } \\
\text { Good }\end{array}$ & $\begin{array}{l}\text { Very } \\
\text { Less }\end{array}$ \\
\hline
\end{tabular}

Based on the table above, if displayed in the form of a diagram the results can be seen as follows:

Figure 2. Achievement Motivation

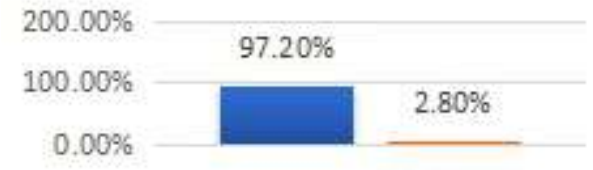

Based on the tables and diagrams above, it can be explained as follows: 
1. An assessment of the achievement motivation of Pencak Silat athletes in Kota Samarinda, which answers yes to the display aspects, shows that the category is very good, with a percentage of $97.20 \%$.

2. The assessment of achievement motivation of pencak silat athletes in Kota Samarinda which answers no to the aspect of display shows that it is in a very good category, with a percentage of $2.80 \%$.

Based on the results of filling out the achievement motivation questionnaire, the Pencak Silat athletes in Samarinda City were very good with a category of $97.20 \%$

\section{CONCLUSIONS}

Based on the results of the research and discussion presented and written by the researcher, it can be concluded that parental support for the achievement motivation of Samarinda City Pencak Silat athletes in the parent support questionnaire is included in the excellent category, with 468 items answered yes or $93.40 \%$. In the questionnaire the achievement motivation is included in the very good category, namely with the number of 486 items that answer yes or equal to $97.20 \%$. These results can be concluded that by gaining the support of their parents the achievements of athletes will improve and also by gaining the support of parents, the contingent of Samarinda City in the Pencak Silat sports group managed to become First Champion by getting 11 gold medals from 21 gold medals contested at Provincial Sports Week VI in East Kutai.

\section{REFERENCES}

Akbar, S. (2013). Istrumen Perangkat Pembelajaran. Bandung:PT Remaja Rosdakarya

Arikunto. S. (2010). Prosedur Penelitian Suatu Pendekatan Praktik. Jakarta: Rineka Cipta.

Bowman, P., Judkins, B.N. (2016). The Invention of Martial Arts. Cardiff University Press.ISSN 2057-5696

Nugroho, A. (2005). Melatih Sikap dan Gerak Dasar Pencak Silat Bagi Pesilat Pemula. Jurnal Olahraga Prestasi. 1 (2), 143-160.

Nugroho, A. (2007). Pedoman Latihan Pencak Silat. Yogyakarta: FIK UNY

Sugiyono. (2013). Metode Penelitian Pendidikan. Bandung: Alfabeta

Wilson,I.D. (2002). The Politics of Inner Power: The Pactice of Pencak Silat in West Java. Murdoch University Western Australia. 